\title{
THREAT PERCEPTION IN ONLINE ANTI-MIGRANT SPEECH: A SLOVENE CASE STUDY
}

\author{
Rok CHITRAKAR
}

Faculty of Arts, University of Ljubljana

Chitrakar, R. (2020): Threat perception in online anti-migrant speech: A Slovene case study. Slovenščina 2.o, 8(1): 66-91.

DOI: https://doi.org/10.4312/slo2.0.2020.1.66-91

\begin{abstract}
The aim of this article is to describe the perception of refugees as a threat in Slovene online discourse, based on a critical analysis of commenters' responses to popular media posts at the height of the European migrant crisis. The proposition of the study is that the perception of migration as a threat is at the core of socially unacceptable discourse (SUD), portraying refugees and migrants as an undesirable and potentially dangerous presence. Within the framework of a comprehensive project examining public responses to media coverage of the arrival of migrants to Slovenia, online comments classified as SUD targeting refugees were extracted and annotated to reveal the recurring themes of threat perception. The analysis focused on describing the main categories of threat, as well as the various discursive features and strategies employed. Although the approach to observing this subject is essentially qualitative, a general case-specific overview of the frequency and distribution of identifiable categories is also given.
\end{abstract}

Keywords: corpus analysis, critical discourse analysis, anti-migrant speech, hate speech, European migration

\section{INTRODUCTION}

In the wake of the war in Syria and the growing involvement of foreign armed forces in the wider regional conflict, Europe was faced with increasing numbers of migrants entering its territories in search of refuge and assistance. The arrival of migrants to Europe reached mass proportions in the second half 
of 2015 and the beginning of 2016 (Kogovšek Šalamon, 2017), demanding a large-scale, concerted response from the European Union and its member states. Countries along the route leading to preferred destinations (Germany or other Western and Northern European countries) were particularly affected, having to provide safe passage as well as the necessary administrative facilities and reception infrastructure to accommodate large numbers of arrivals. For Slovenia, the turning point came when Hungarian authorities decided to prevent migrants from boarding trains and continuing their journey toward Austria and Germany and, ultimately, closed the country's borders with Serbia and Croatia (BBC, 2015). With Hungary securing its borders and Croatia unwilling to accept returns, the migrants' path was rerouted through Slovenia, placing it within the newly established humanitarian corridor, in operation from October 2015 until March the next year. The countries along the Western Balkan Route, running through Greece, Macedonia, Serbia, Croatia, and Slovenia to Austria and Germany, had to provide transport, food, shelter and medical assistance to migrants in transition, which put a significant strain on their capacities and resources.

Officials, the civil society and humanitarian organizations all contributed to managing the situation by providing staff, facilities and logistical support (Ladić \& Vučko, 2016). However, due to exceptionally high numbers of migrants arriving at the time, it became evident that these countries were largely underprepared and not able to rely on an adequate response mechanism to deal with these exceptional circumstances. Migrants were often met with increasingly difficult conditions, having to face long waits in overcrowded and poorly managed ad hoc reception centers and fenced off camps. Living conditions in these areas were at times bad enough to threaten their survival en route and could, in the worst cases, be interpreted as a clear violation of human rights. The corridor continued to be in operation until March 2016, when Turkey, within the framework of the EU-Turkey Statement (European Council, 2016), started opening its labor market to Syrians under temporary protection, accepted a large investment into its refugee reception facilities, and agreed to rapid returns of migrants declared ineligible for international protection. These measures led to the decrease in the use and gradual phasing out of the corridor, with the remaining groups of migrants applying for 
asylum. Nationals from Syria, Iraq and Afghanistan (SIA) were granted special status, while others, undocumented SIA citizens included, encountered less favorable conditions and were not allowed to proceed with their journey (Kogovšek Šalamon, 2017, p. 260). Because of widespread concerns over the authorities' ability to manage the migrant situation and rising tensions in refugee hotspots, at times resulting in violent altercations and material damage, the Slovene media extensively covered this issue. Continuous exposure in conjunction with Parliamentary debates and various civil initiatives, such as awareness raising campaigns, framed the general public discourse. The exchange of opinions was particularly intense in social media, where Twitter and Facebook were permeated with argumentative and oppositional discourse. The social media platforms were transformed into a repository of different forms of socially unacceptable discourse (SUD), ranging from the more implicitly offensive and discriminative comments to overtly threatening hate speech and incitation to violence.

This article aims to examine and describe some of the ways in which migrants and refugees are perceived in socially unacceptable discourse in Slovenia. The basis for this discussion will be the assumption that participants in anti-migrant online discourse mostly act and react out of a sense of fear or threat linked to the presence of migrants directly, or to the presumed negative effects of migration as a phenomenon in general. To support this claim, we will rely on the principles of critical discourse analysis (van Dijk, 2001), a theoretical framework for describing how social dominance and relations are asserted through language use. The role of discourse in establishing social inequality and maintaining the distribution and reproduction of power (Fairclough, 2001) has already been amply discussed and demonstrated. As an approach, combining corpus studies, based on extensive datasets of actual language use, with critical discourse analysis (CDA) has proven to be efficient in researching discursive features (Baker, 2008), which is especially relevant when analyzing discourse aimed at vulnerable groups, such as migrants and asylum seekers.

According to Hatebase, a large database of multilingual hate speech, extreme forms of SUD most frequently target individuals on the basis of their ${ }^{1} 1$ ) ethnicity, 2) nationality, and 3) religion (Sindoni, 2018, p. 270). This finding

1 In order of importance. 
places refugees and migrants in the context of the European migration crisis (for example Arab, Syrian, Muslim) among those most likely to find themselves at the center of discrimination, exclusion, and socially unacceptable discourse. Computer-mediated communication (CMC), interactional discourse retrieved from social media genres including popular social networks (Beißwenger, Horsmann \& Zesch, 2018), represents an important segment of language use that significantly contributes to the formation of new social practices and accepted concepts of normality, within the confines of which traditional meanings and established power relations are maintained and consolidated (Gorjanc \& Fišer, 2018; Gorjanc \& Fišer, 2020). This study will attempt to provide some insight into how online socially unacceptable discourse, as an important component of increasingly present discriminative and exclusive attitudes, forms the perceived identity of refugees and migrants in Slovene society.

\section{RELATED RESEARCH}

Research dealing with the issue of SUD directed at migrants, either on the level of conflict-driven migrations in general (Baker \& McEnery, 2005; Wodak \& Boukala, 2015) or within the specific context of Slovenia and its role in the European migration crisis (Erjavec \& Kovačič, 2012; Ladić \& Vučko, 2016; Vezovnik, 2017; Vehovar et al., 2020), already points out some of the prevalent features of anti-migrant speech that are likely to occur during analysis. From the point of view of threat construction and reproduction, various forms of negative portrayal of migrants as a distinctive social group by means of risk-related framing, othering, dehumanization, and vilification will be at the forefront of our attention.

Framing, a process by which the media and other influential discursive agents (e.g. political actors) emphasize a certain aspect of reality (Keren, 2011), is employed to establish specific meanings and ways of interpreting issues or events, such as the arrival of migrants. This is an important factor that plays a crucial role in predetermining the tone of discussion and, as certainly is the case with migrants in Slovenia, provides fertile grounds for SUD to develop and prosper. By focusing on a certain subject and consistently framing it in terms of risk and danger, discursive agents can already set the main themes 
around which SUD will revolve. Negative representations of migrants in media are common, and their portrayal as a threat to society is typically shaped along several main argumentative lines. Innes (2010), examining the framing and perception of asylum seekers in British media narratives, recognizes three distinct categories of threat: 1) physical threat to society and its members, formulated in terms of sovereignty and security, 2) economic threat, wherein migrants are shown as undermining or exploiting social welfare, and 3) cultural threat, related to endangering and eroding social and cultural values.

In order to legitimize the construction of threat in socially unacceptable discourse, a clear distinction is made between the group presented as the threat and the group believed to be threatened. This is largely achieved by establishing an us/them opposition, where a rhetoric of exclusion is employed to delimit a European us from the non-European other (Wodak \& Boukala, 2015). The first is usually represented as the potential victim, while the latter is portrayed as the probable offender to whom an infinite number of negative qualifiers and characteristics may be ascribed. Within various mechanisms of othering, migrants and refugees are commonly conflated into the out-group, culturally dissimilar from the host society and politicized as an invasive element that should be feared and distrusted (Huysmans, 2006). In addition, the process of social categorization, reinforced through language used in social media, effectively contributes to solidifying ideas of in-group homogeneity and solidarity between those under presumed threat (Waldron, 2012).

The negative representation of migrants should also be viewed in the context of securitization (Buzan et al., 1998), where critical discourse analysis can be used as a tool to explore the textual mechanisms behind the perception of migrants as a security threat. Discussing the media representation of migrants as a security threat in Slovene public discourse, Vezovnik (2017, p. 48) points out the common phenomenon of dividing arrivals to Slovenia into the categories of the genuine and the bogus, a clear example of a discursive attempt to criminalize refugees by turning them into subjects deserving increased suspicion. She also emphasizes that references to securitization on the Slovene-Croatian border could be interpreted as an indication of how talk about protection and defense may lead to actual security actions (2017, p. 50). 
Another function of extreme forms of socially unacceptable discourse is to degrade and dehumanize target individuals or groups, stripping them of human characteristics that would generally warrant empathy and solidarity. When, for example, migrants are portrayed not as human individuals, but as an unfeeling personification of a natural disaster on a collision course with the host society, harsh and decisive counter-measures may seem much more acceptable. Similarly, the notion of mass, as often deployed in SUD, can be used as an effective discursive strategy. Van Dijk (1991) refers to the aggregation technique, by way of which the targeted group of discourse participants is objectified and treated as statistics. The use of numbers and figures as a discursive tool has a double effect; it gives the impression of neutrality, of merely reporting the factual truth, while social groups represented in the form of aggregated data or numbers can easily create the sense of too many (Vezovnik, 2017, p. 47).

The examples stated above are among some of the common features present in anti-migrant discourse that this study will attempt to highlight. In the framework of critical discourse analysis, examples of SUD and hate speech offer abundant material for criticism and discussion. One of the principle goals of such research is to expose and condemn the construction of discriminative and exclusive discursive practices that can, in the worst of cases, lead to violence against targeted groups and individuals. However, an additional aim of this article is to gain a deeper understanding of the root causes for the development and reinforcement of such practices. As suggested by Erjavec and Kovačič (2012), it is also important to focus on the individuals who produce SUD and hate speech in the attempt to understand their motivations for inciting hatred. By doing so, we might be able to move away from the individual conflicts and opposition between social actors and groups participating in the argument, and gain insight into some of the broader, systemic issues that lie underneath.

\section{RESEARCH CONTEXT AND METHODOLOGY}

Before describing the methodological approach applied to dataset selection and analysis in this study, a more general presentation of the research context should be given. This work is part of a wider, comprehensive project examining 
the issue of socially unacceptable discourse in a multidisciplinary framework combining corpus linguistics, CDA, legal analysis and sociological survey methods (Fišer et al., 2017). With a view to researching the construction, use and perception of SUD in a multifaceted sociocultural context, the project partners (the Department of Knowledge Technologies at the Jožef Stefan Institute, the Faculty of Arts, the Faculty of Social Science, and the Peace Institute, all in Ljubljana) developed large corpora of computer-mediated communication (CMC) and SUD, focusing on social media and online networking sites. As textual forms of CMC offer easily accessible and downloadable language data, they were chosen as the basis for an interdisciplinary sociolinguistic analysis. In the case of the SUD corpus, a list of Facebook groups in which such forms of speech frequently occur was compiled and used as a source for harvesting targeted data that would be included in the final dataset. After identifying the most visited Slovene mainstream media websites (24ur.com, SiOL.net.Novice, and Nova24TV), their Facebook pages were selected for inclusion in the repository of SUD comments.

The crucial phase before any analysis could take place was to produce an annotation schema and guidelines, according to which the type and target of socially unacceptable discourse could be determined. A two-dimensional typology was developed, taking into account six types of SUD and five targets at which SUD is directed (Ljubešić et al., 2019, p. 4). In relation to this study, SUD could be perceived as (1) aimed at migrants, (2) aimed at individuals or groups related to migrants, (3) aimed at media or journalists, (4) aimed at other commenters participating in the discussion thread, or (5) aimed at someone else. In terms of type, the main distinctions in annotating individual comments were made when determining whether (YES/NO) SUD was aimed at background (e.g. religion, ethnicity), or other groups/individuals, and whether it contained elements of violence. A manual annotation campaign was carried out after specific training was given to a select group of annotators (Ljubešić et al., 2019, p. 5) to ensure the best possible level of consistency and consensus in the results acquired. In the next phase, an in-depth analysis of the manually annotated dataset was performed, highlighting several findings relevant to this study. Perhaps the most revealing conclusions came from an overview of annotation distribution, which showed that only about half of 
the annotated comments were classified as socially acceptable, a low number in the context of a public discussion. One of the conclusions that could be considered especially alarming pointed out that SUD inciting violence toward migrants was present in seven percent of annotations (Ljubešić et al., 2019, p. 8). This confirms the potential harmfulness of SUD as a form of widespread discursive practice that needs to be thoroughly researched and continually brought to the attention of regulatory actors and the general public alike.

In the second stage of annotation, the dataset was adapted specifically to the aims of this study, which required focusing predominantly on the anti-migrant component of socially unacceptable discourse. This entailed narrowing down the initial dataset pertaining to the general topic of migrants by reducing it to those comments where migrants were directly or indirectly targeted. In other words, comments in which SUD was aimed at media, other participants in the discussion thread, or someone else entirely, were deleted from the annotated dataset to be used for subsequent analysis. As the principal subject of this study was to analyze how negative and discriminatory perception of migrants was constructed and reproduced by anti-migrant commenters, it seemed relevant to create a clear opposition between the in-group and the out-group by excluding other actors who entered the discourse dynamic in a more complementary way. The final dataset contained three possible combinations of annotated comments: (1) comments referring to background, aimed at migrants, using offensive language, (2) comments referring to background, aimed at migrants, inciting violence, and (3) comments referring to others, using offensive language, related to migrants.

\section{ANALYSis AND RESULTS}

After the comments relevant to this study were selected and annotated, a preliminary qualitative analysis was performed to obtain a general sense of how SUD aimed at migrants was reflected in language use and the argumentative strategies employed. This proved to be a critical moment in the study, as it determined the direction of the adopted approach. The principal observation that became apparent during the first analysis of the selected comments was that SUD targeting migrants could indeed be identified as a form of response to various, recurring types of threat perceived by discourse participants. The 
comments that contained an argumentative element, as opposed to being purely offensive or inciting violence, could all be grouped according to several major topics repeated throughout the threads. After completing the analysis which focused on the different types of threat perception reflected in the comments, the following major categories were identified: (1) physical threat, (2) threat of Islamization, (3) threat of infiltration, (4) economic threat, (5) sociocultural threat, and (6) referential threat.

Another round of annotation was now performed to indicate the category of threat perception that each of the comments belonged to. This was done by an individual annotator (the author of this paper) with the purpose of facilitating a more detailed qualitative analysis. In addition to enabling a more systematic approach to examining anti-migrant SUD by grouping the comments into more or less distinctive themes, this method also made it possible to obtain a general overview of their distribution. First, a comparison was made between comments that contained a mention of threat perception related to migrants, and comments that contained no such reference. The latter were examples of purely offensive comments, hate speech, or outright incitation to violence against migrants, and had no argumentative value. Considering the fact that SUD in which threat perception was identified is divided into six additional categories, this indicates a significant prevalence of comments (nearly half) where no reason or justification for rejecting or targeting migrants is provided or deemed necessary.

Table 1: Percentage of threat perception identified in SUD

\begin{tabular}{l|l}
\hline SUD, threat perception identified & SUD, threat perception not identified \\
\hline $58 \%$ & $42 \%$ \\
\hline
\end{tabular}

This was followed by a breakdown of different categories of threat perception in terms of distribution, yielding the following results:

Table 2: Breakdown of threat perception categories

\begin{tabular}{l|l}
\hline Physical threat & $33 \%$ \\
\hline Threat of Islamization & $22 \%$ \\
\hline Threat of infiltration & $19 \%$ \\
\hline Economic threat & $14 \%$ \\
\hline Sociocultural threat & $7 \%$ \\
\hline Referential threat & $5 \%$ \\
\hline
\end{tabular}


It should be noted that these results are of indicative nature, as additional annotation was only carried out by one person and the quantitative distribution of individual themes was, to a certain extent, predetermined by the content of posts to which commenters were responding. However, some of the topics identified in this case study have proven to be prevalent throughout the threads analyzed. Viewing migrants as a potential physical threat was clearly the main concern for most of the commenters participating in the discussion. The fear of imminent danger in the form of physical violation or even death is, perhaps not surprisingly, much greater than, for example, anxieties related to the possibility of sociocultural disruption. The threat of Islamization and the threat of infiltration, at times overlapping and appearing within the same comment, seem to carry comparable weight. On the following pages, a more detailed description of individual categories, with examples taken from the analyzed threads, will be given to highlight the diverse discursive strategies and approaches to portraying migrants as a form of threat in socially unacceptable discourse.

\section{DESCRIPTION OF IDENTIFIED THREAT CATEGORIES}

\subsection{Physical threat}

The most easily identifiable and largest category of threat, directly attributed to the arrival of refugees and migrants, reflected the commenters' fear of material damage, outbreaks of violence, violation of physical integrity and, ultimately, death. The potential of physical danger underlying negative attitudes to migration elicited the most emotional and violent responses. In the context of the Slovene migration crisis, commenters often alluded to the need to regain control over an out-of-hand situation to protect themselves and, perhaps more importantly, their families. Women and children, in particular, were singled out as the most vulnerable group in need of protection. To support and justify these concerns, commenters often resorted to citing recent events, such as cases of rape and violence reported in relation to migrants, mediatized across Europe. Western, non-Muslim women were claimed to be most exposed to possible physical attacks by refugees and migrants, as they were considered most likely to present an affront to the Muslim faith.

The safety of public spaces where migrants were now a growing presence was also called into question, especially in terms of limited freedom of movement 
and obstacles to the established way of life (not being able to go out at night). Generally speaking, in a post 9/11 world and in the light of terrorist attacks occurring across Europe (the Paris attacks, what happened in Brussels), refugees and migrants as the out-group were identified with terrorists, criminals, savages, aggressors, extremists, combatants, jihadists, hooligans, and ISIS. The visual portrayal of migrants in the media also played an important role in forming the general perception of physical threat. Commenters often referred to the fact that newspaper images and televised footage showed groups of strong, combat-ready, young, 16-45 year old men, which likely contributed to establishing associative links with organized units, military stratagems and planned invasion.

Preference for the visual framing of refugees as a threat was most evident in graphic references to scenes of extreme violence, mentioning decapitation, throats cut, bombs exploding, stoning, and child bombers, among others. Extremist iconography specific to acts of terrorism and war (black flags, Kalashnikovs, beards, shouts of Allahu Akbar) was frequently used to evoke a sense of dread at the arrival of Muslim population. Also on the symbolic level, important landmarks of the Muslim community in Europe were given negative connotations. Mosques and Muslim cultural spaces, for example, were associated with terrorist training centers and images of children cutting heads off teddy bears. Another aspect of physical threat that was widely referred to were alleged health hazards and security risks associated with the arrival of refugees to Europe. This was in line with similar discursive approaches aimed at dehumanizing migrants who were, in this case, depicted as carriers of disease, dirty, defecating in the streets, leaving trash everywhere, and even as a cancer, ready to metastasize across Europe.

The perception of physical threat also established the parameters of internal dispute present throughout the threads analyzed. The main argumentative opposition was created between those who categorically rejected refugees and those who defended them, namely pro-migrant activists who participated in protest rallies and welcomed migrants at the borders. The latter were seen as facilitators in the process of migration, and as such an important part of the problem (idiots, traitors) that, much like refugees, needed to be eradicated. Interestingly, this opposition also encouraged the usual antagonism between 
the center (Ljubljana, the capital of Slovenia) and the periphery, the center generally being seen as more liberal and supportive of migrant integration. In addition, the government and political actors were blamed for failing to adequately address national security concerns and putting the country and its citizens at risk by helping the enemy. Throughout the threads, commenters emphasized their concerns over the potential physical threat posed by refugees by calling on the government to protect their own. Along with the anti-migrant public, pro-migrant activists, and the media, government actors formed the discursive frame for the entire discussion.

\subsection{Threat of Islamization}

The next major topic that emerged from examining the comments for identifiable types of threat perception was centered on Islamization. In this case, migrants were perceived as the driving force of a potential Muslim invasion of Europe. In certain regards, this category of threat perception overlapped with the fear of physical harm, but this was conveyed indirectly, by referring to religion. The Muslim faith was portrayed as the basis for extremist violence and terrorism, giving migrants and refugees a license to kill, break our laws because their religion tells them to, or enforce their religion. Commenters also resorted to quoting decontextualized parts of the Qur'an to illustrate Muslim migrants' intentions. This proved to be a popular argumentative strategy, supposedly providing proof that needs no further explanation, but speaks for itself. Again, the threat to the European way of life was placed in the foreground (ex. not being able to eat pork), with women repeatedly mentioned as the primary victims, especially in terms of losing rights and diminished equality.

The concept of invasion was at the core of the discussion. Most of the fears revolved around migrants invading our homes, taking our property, or taking the throne, a process through which Europeans would become subjugated, even enslaved under the Muslim rule. This hypothetical invasion of Europe was characterized as calculated and planned, as a gradual transformation in a grand scheme of global domination, implemented methodically and systematically through the construction of mosques and Muslim schools, as well as the spread of Muslim ghettos. Some commenters claimed that one of the 
main threats associated with migration from Muslim countries would be substitution. This would occur on several levels, a logic according to which the Constitution would be replaced with Sharia law, universities with madrasas and women's skirts with headscarves.

Conspiratorial undertones were present throughout this segment of discussion with theories proposed of Arab countries financing or bribing the authorities to allow invasion as a form of neocolonialism that would eventually lead to the destruction of European cities. Referring to historical experience was also one of the favored lines of argumentation, aimed at reducing the Muslim population to the role of invader within the context of an envisioned large-scale clash of civilizations (they have always been the enemy, What did our forefathers fight for?). Cautionary examples were also provided, with allusions, for instance, to the French who opened their doors and are now the minority, with $64 \%$ of schoolchildren being Muslim.

This brings us to the question of statistics, often provided as argumentative evidence in favor of the validity and credibility of posted comments. Commenters opposing the arrival of refugees seemed to have a wide array of numerical data at their disposal whenever they needed to illustrate the severity of the migrant situation. However, when these statistics are not supported with a clear reference to their source, one has to wonder about their veracity. It is important to note that such data, tailored to fit a specific purpose and sometimes even altogether invented, can serve as an effective discursive device (van Dijk, 1991). When it comes to constructing threat as a means to legitimate socially unacceptable discourse, describing a situation where 10000,20000 , or 50 ooo refugees are crossing the border into a small and underprepared European country can paint a convincing picture.

In fact, responding to the threat or fear of invasion is often related to various ways of interpreting and expressing the central notion of mass. When discussing the issue of mass migration in terms of amount, commenters tended to highlight the omnipresence and multitude of migrants who, in their opinion, were everywhere, on our front lawns, in the fields, around our houses, and in great numbers, hordes that would eventually run us over. Parallels were frequently drawn between migrants and natural disasters, typically in the form of metaphors of water flow, calling our attention to the risk of drowning or 
becoming submerged, overflown and, conversely, to the necessity of building a dam, stemming the flow. Other dehumanizing comments, related to the threat of mass invasion, portrayed migrants as an infestation (vermin, rats) or an epidemic (plague), and even expanded to legal interpretations of the EU provisions on family reunification (Council Directive 2003/86/EC), which might enable migrants to abuse rules in order to multiply.

\section{$5 \cdot 3$ Threat of infiltration}

The threat of invasion in the context of migration often presupposes an act of infiltration committed by members of the out-group. This was identified as the next category of threat perception within which the status of refugees is constantly questioned or, in most cases of anti-migrant speech, altogether rejected. The logic of undermining the status of migrants escaping areas of war and conflict is based on the imperative that only individuals who can be classified as refugees according to international law are deserving of help. Immediately, this precept introduces the hypothetical possibility, and consequently threat, of persons willing to abuse such legal provisions and attempt to enter a country as fake refugees. To add an additional layer of complexity, the issue of identifying and correctly using the notion of refugee, as compared to migrant, immigrant and emigrant, seems to cause a fair amount of confusion in public discussions, as these terms are often used interchangeably, without discerning relevant semantic nuances. That aside, the most frequently used discursive technique commenters applied to dealing with the threat of potential infiltrators almost invariably followed the formulaic They are not refugees, they are... The blank space would then be filled with any number of qualifiers readily available to discredit the status and intentions of refugees, among which the most common were terrorists, criminals, economic migrants, opportunists, cowards, traitors, and fake, so-called, illegal or quasi- refugees.

Migrants were generally subjected to a form of group profiling, especially on the grounds of the images shown in mainstream media as well as other, alternative sources of information. For example, the repeatedly emphasized image of mostly male, young, combat-ready, healthy, strong men was quite evidently used to insinuate that migrants were to be treated as a threatening 
new presence with a hidden, sinister agenda. Determining migrants' age and sex was mentioned as the crucial stage when screening for potentially trustworthy refugees. Again, the risk of persons attempting to abuse established legal provisions, such as the frequently cited unaccompanied minors clause (Directive 2011/95/EU of the European Parliament and of the Council), was brought to the foreground with accusations of migrants lying about their age and references to bearded children. Another argument that was used to undermine refugees' credibility was directed purely at personal appearance; the idea of war refugees still seems to be visually rooted in images of starvation and torn clothing, as opposed to nice clothes and expensive smartphones.

Throughout the timeline of the posted threads, media reports provided continuous support for rejecting refugees. The newcomers' unwillingness or inability to present acceptable identification as proof of their status, a precondition for assistance and possible entry, was a particularly salient point (If they really are refugees, why won't they prove it?). In general, the behavior of migrants during the reception and identification procedure at the borders was extensively covered by the Slovene media and closely scrutinized by the public. When questioning the status and eligibility of migrants as a group, commenters relied on specific, widely mediatized events showing individuals refusing assistance (Slovenske novice, 2015). Rejecting food and clothes, for example, was perceived as ungrateful, in turn supporting the claim that migrants did not deserve to be helped. It was also made clear that refugees were not expected to complain or make demands, and should be content with any kind of assistance offered.

The migrants' demands to choose their country of destination were heavily criticized, but sparked a curious and almost contradictory discussion in which commenters were rejecting their credibility while, at the same time, struggling with feelings of wounded pride (We don't want them, but why won't they stay?). This line of argumentation (Ladić \& Vučko, 2016) was also complemented by the first safe country principle (Regulation 604/2013/EU of the European Parliament and of the Council), according to which refugees were expected to seek asylum as soon as they escaped danger, and not to continue travelling in search of a better life. Even when the status of refugees was recognized, attempts were made to undermine their character. In this case, 
migrants and refugees were portrayed as cowards, deserters, or traitors who gave up their homeland without a fight, and left their elderly and women behind. Within this category of threat perception, a significant amount of distrust was also aimed at the media, who were accused of intentionally portraying migrants as a vulnerable group, in need of help. Commenters were particularly active in highlighting the media's agenda of manipulating the public opinion by selective reporting, only displaying certain content while covering up the negative. This is an interesting claim, especially considering the fact that anti-migrant commenters have a clearly ambivalent and selective relationship with media, whose information can be used or discarded at will, according to discursive needs.

\subsection{Economic threat}

The following category of threat perception was based on rejecting the status of refugees who were generally labeled as economic migrants, in order to emphasize what commenters believed to be the true nature and purpose of migration. Even though migrants and refugees remained the nominal target of socially unacceptable discourse within this topic, in comparison with the other recurrent themes, the argumentation provided here was much more a reflection of the commenters' discontent with the general economic situation. The issue of poverty in Slovenia seemed to be at the core of commenters' concerns, pointing out that while our children are hungry and parents aren't able to afford school meals, refugees could not be treated as a priority. Personal struggles ( $I$ can barely make it through the month myself...) and the added fear of having to provide for refugees' subsistence could be seen as a decisive factor in refusing to accept migrants. In this context, political actors were singled out as the main culprits responsible for the failing economy, and the government was accused of not providing for their own citizens while giving more benefits to refugees than to Slovenes. The media attention given to refugees was also a sore spot (When have they ever cared about us, talked about our problems?) and, in response, vulnerable members of the in-group, i.e. Slovene citizens, were prioritized (the children, the elderly, the unemployed, the indebted).

The presence of refugees was perceived as a potential impediment to improving the economic situation as well as a burden to the social welfare system that 
could find itself at risk if the State needed to provide for migrants. The willingness to accept and integrate refugees was generally equated with transferring funds from social welfare to migration policy, for example from child support and schooling to refugee reception facilities. A strong sense of ownership over the way the national budget was employed in dealing with migration was also expressed, further stressing the imminence of the supposed threat (taxpayers' money, our money, money from our pockets). Among the comments directly targeting migrants as agents of possible economic ruin, many were directed at portraying them as lazy, not willing to work for their money, or not used to work, with frequent insinuations about an alleged growing criminal presence (thieves). Commenters also resorted to dehumanizing strategies within this segment of anti-migrant speech, mostly by referring to the burden of having to feed these so-called refugees or leeches, and insisted on shifting financial responsibility for doing so to those willing to help (namely pro-migrant activists and politicians).

\subsection{Sociocultural threat}

When discussing the perception of migrants and refugees as a sociocultural threat in Slovenia, we will be focusing on how migratory flows were seen and presented as a disruptive force in the societal and cultural landscape. The starting point of argumentation within this category of threat perception was the assumption that refugees and migrants were unwilling or unable to integrate with the host society. Among the principal claims propagated by commenters was the categorical statement that migrants are not capable of respecting our legal order and would try to enforce their order and traditions. General judgments, such as they're not good at integrating, were highlighted as an accepted truth, supported by references to migrants' insistence on pursuing a completely different lifestyle (wearing headscarves in public, for example).

Constructing the image of out-group inferiority was another popular discursive strategy. The alleged difficulty in integrating migrants was, for instance, attributed to their not speaking English, not being educated or not being able to understand our laws, our ways. To reinforce the validity of this negative image, commenters referred to past experiences with refugees, some of who have lived here for decades and still haven't learned to speak a word of 
Slovene. Where refugees and migrants were given an active role in terms of responsibility for integrating, the discussion was deeply anchored in the paradigm of a host-guest dynamic, according to which they should try to adapt, should be respectful and should not get too comfortable. In a reversal of roles, a much more positive light was shed on members of the in-group who would accept their rules and their culture if they were in their place, setting an example of proper behavior.

A clear conditionality was attached to the possibility of welcoming refugees and migrants, with commenters stating they would be willing to accept them if they gave up their ways and lived according to our rules. This could, however, prove to be a difficult condition to fulfill, as it implies the necessity of migrants discarding their identity in order to erase their otherness. Sometimes the fear of otherness, as reflected in the comments analyzed, was of purely superficial nature, and migrants were perceived as a foreign element with which contact was undesirable and difficult to imagine (women dressed like mummies sitting in my living room). On the other hand, the difficulty of including and integrating migrants in the host society was viewed as an inherent and unchangeable part of the problematic itself. Clear lines of separation were drawn to demonstrate the incompatibility of migrants with the Slovene society and culture, by emphasizing the inevitable clash between mentalities and, in particular, religions (Islam does not allow for integration).

Integration in the context of religious identity was also seen as improbable due to migrants' supposed isolationism, their tendency to function exclusively within family units, closed communities, or Muslim ghettoes, and build their own environment (mosques, schools, media) instead of adapting. With this, the logic underlying the various claims of dangers contained in possible non-integration came full circle; the failure to integrate migrants and refugees could lead to their marginalization, which could in turn foster feelings of discontent and resentment, ultimately leading to physical retribution. Perhaps to alleviate the overarching sentiment of xenophobia, a curious comparison was made to Bosnian refugees that arrived to Slovenia during the Yugoslav Wars. Despite well-known discriminative and prejudiced attitudes against Yugoslav immigrants, particularly pronounced at the time, but still present today, they were now portrayed as model refugees, acceptable due to linguistic and 
geographic proximity, not savages but civilized like us. As a more appropriate solution, commenters suggested that migrants who were too different should instead head to neighboring countries where the way of life is similar and it's easier for them to integrate.

\subsection{Referential threat}

As opposed to other identified groups of threat perception, the final category examined was related to migrants and refugees indirectly, usually by providing links to other articles and videos, by quoting influential figures (Gaddafi said..., An interesting quote by Geert Wilders...), or by explicitly referring to media as the incontestable source of information. The formulation of socially unacceptable discourse through various means of reference is a particularly interesting phenomenon. Here, the commenter is not the immediate source of the content given, nor does she explicitly agree with the content referred to. In the case of The answer is clear ... https://www.youtube.com/watch?v=EZbCK95Zu_o, or This video says it all ... https://www.youtube.com/watch?v=X2rmA9A7CEM, the analyst is required to proceed with a second phase of examination to verify the nature of the comment. Of course, other links may be explicit enough as to their aim and content without much further investigation, for example This is what I thought: http://pamelageller.com/2015/09/document-muslim-migrantsraping-women-and-children-in-camp-in-germany.html/ or And this: http://vladtepesblog. com/2015/09/12/rape-and-forced-prostitution-common-in-muslim-refugee-camps-in-germany/, giving a clear enough indication of the statement contained.

Whether a link was sufficiently descriptive or required the implications of its contents to be deduced from a broader discursive context, the common denominator underlying this form of socially unacceptable discourse was most evident in the shift to a more personal level of commenting. Commenters were now referring to specific, heavily mediatized images and situations, and were speaking directly against subjects in photographs and videos, viewed as the main actors personifying the encroaching threat of migration. Audiovisual content was appended as self-evident truth, entirely exempt of critical thought (We all saw on TV... Watch the footage...), and provided a readily available opportunity to reinforce solidarity between like-minded commenters who could simply voice their agreement (I agree, exactly right, well put). 
In addition to being a communicative facilitator and an effective argumentative strategy, establishing threat by way of reference also functioned as a tool of empowerment, specifically when opposing mainstream media or pro-migrant activists. When the need to bolster a personal opinion arose, commenters could readily access and select information, according to their discursive needs (Just GOOGLE it!). In and of itself, taking personal initiative in gathering information is by no means problematic and can indeed contribute to a better grasp of a multifaceted subject, such as migration. However, in the context of socially unacceptable discourse, the tendency to decontextualize facts and information most often only serves the creation and reproduction of potentially harmful biases.

\section{DISCUSSION}

The qualitative analysis of comments in Slovene social media, carried out within the framework of this case study, has confirmed the importance of the perception of refugees and migrants as a threat in the formation, consolidation, and reproduction of socially unacceptable discourse. Examining the discursive mechanisms and strategies underlying this practice provides insight into the various motivations for anti-migrant speech. It also reveals how key discursive actors, such as politicians and the media, contribute to the construction of the targeted out-group as a threat, by relying on narrative framing that effectively elicits feelings of fear that are often at the root of social exclusion, discrimination, and rejection.

The recurrent topics that are central to anti-migrant speech in Slovene online discourse have made it possible to identify several categories of threat perception, within which commenters typically present arguments to justify or legitimize their rejection of refugees and migrants. In order of importance, migrants and refugees were perceived as presenting a threat in the form of (1) physical danger, (2) Islamization, (3) infiltration, (4) economic burden, and (5) sociocultural disruption, with an additional category of (6) referential threat also identified to take into account arguments presented indirectly, by way of reference.

The quantitative distribution of comments according to different threat categories, although indicative and case specific, implies that the fear of physical 
harm is at the forefront of motivations underlying the negative and discriminative attitudes against refugees and migrants, as reflected in SUD. This shows that the direct threat associated with the presence of migrants and refugees takes precedence over other, more abstract concerns, such as the potential for sociocultural disruption. The noticeable prevalence of the sense of physical threat among anti-migrant commenters would also be in line with the media's negative framing of the migration phenomenon, as well as the enhanced securitization at the political level.

This leads to questions about a possible feedback loop between different, multi-level types of responses that can perpetuate negative and exclusive attitudes against members of an out-group. Considering the fact that most of the examples of SUD found in online comments follow a similar argumentative logic and employ well-known and predictable discursive techniques, it is not difficult to imagine the automatization of anti-migrant speech in computer-mediated communication. As this presents an increased potential for spreading and reproducing harmful SUD and hate speech, adequate responses should be developed and implemented by policy-makers and social media platforms alike.

This is, of course, a complex legal issue, inseparably intertwined with the principles of fundamental freedoms, privacy and the rule of law, so finding a balanced solution would require a comprehensive multi-disciplinary approach. In terms of raising public awareness, CDA and other forms of sociolinguistic analysis should attempt to highlight the need to question some of the arguments presented, especially when stated as facts or accepted truths, relying on unverified statistical support and external references so freely given as "evidence". Such studies could also lead to a more thorough discussion about the issue of attributing and accepting social accountability for discriminative and exclusive practices in the context of public discourse.

In addition to the important role played by those wielding discursive power, both in pre-determining and shaping the established narratives pertaining to members of the out-groups deemed threatening, SUD could also be seen as an indirect, yet relevant, criticism of society. Even though most of the anti-migrant SUD, observed on the textual level in this case study, was aimed directly at migrants or their religious and ethnic backgrounds, many of the 
arguments did, in fact, reflect Slovenes' growing dissatisfaction and frustration with the economy, politics, and the State itself. Along with the relevant work of revealing the harmful and widespread effects of socially and democratically disruptive discursive practices and highlighting the many forms in which language use allows them to manifest, an equal measure of attention should also be given to the broader context and the root systemic causes that lay beneath.

\section{CONCLUSION}

The study confirmed the central role of threat perception in the formation of online anti-migrant speech as a subcategory of socially unacceptable discourse in Slovenia. In fact, some form of threat perception was identified in more than half (58\%) of the comments analyzed. This finding should be viewed in light of the fact that in the remaining $42 \%$ of the cases, in which threat perception could not be pointed out, commenters gave no reason or justification for targeting migrants. These comments were, for the most part, examples of pure hate speech in the form of insults and incitation to violence. This means that whenever a comment was based on actual argumentative content, it could be linked to one of the categories of threat perception identified. The analysis of comments targeting migrants and refugees revealed six recurrent themes that permeated the debate about the European migration crisis.

The results indicated that anti-migrant speech was predominantly fear-driven, with one of the main concerns expressed related to the immediate physical threat allegedly posed by migrants arriving to Slovenia. Interestingly, the comments from this category of threat perception were the least substantiated and seemed heavily influenced by sensationalist media reporting. Arguments that provided more explanatory basis, such as those related to the fear of economic deterioration or sociocultural displacement, were far less frequent. Despite the fact that migrants were the primary target of SUD in this case study, a closer examination of the comments also confirmed the commenters' dissatisfaction and frustration with the state and the way the political leadership has handled the situation. The perception of threat in the context of anti-migrant speech often stems from difficult personal circumstances in which the arrival of migrants and refugees may be seen as an aggravating factor. 
As referring to media reports and various opinion makers with the aim of legitimizing anti-migrant comments is a widely used strategy in online SUD, more research should be focused on how influential discursive actors contribute to establishing the framework for intolerant, discriminative and otherwise harmful speech. Accountability for disseminating negative attitudes toward vulnerable minority groups should be highlighted and discussed. An in-depth examination of discursive devices most frequently and effectively deployed in SUD is crucial to understanding, recognizing, and being able to respond to online hate speech. Also, an ongoing and regularly updated overview of online SUD would be useful in following current topical and argumentative trends that should be addressed in public debate when speaking against hate speech. It is particularly worrying that the many forms of socially unacceptable discourse so often remain unrecognized by those who help create it, until they become ingrained in the public conscience as part of the new normal.

\section{Acknowledgments}

The author acknowledges the financial support from the Slovenian Research Agency (research core funding No. P6-0215).

\section{REFERENCES}

Baider, F., \& Kopytowska, M. (2018). Narrating hostility, challenging hostile narratives. Lodz Papers in Pragmatics, 14(1), 1-24.

Baker, P., \& McEnery, T. (2005). A Corpus-based Approach to Discourses of Refugees and Asylum Seekers in UN and Newspaper Texts. Journal of Language and Politics, 4(2), 197-226.

BBC News (2015). Migrant crisis: Hungary closes border with Croatia. Retrieved from https://www.bbc.com/news/world-europe-34556682

Beißwenger, M., Horsmann, T., \& Zesch, T. (2018). Part-of-speech tagging for corpora of computer-mediated communication: a case study on finding rare phenomena. In D. Fišer \& M. Beißwenger (Eds.), Investigating Computer-Mediated Communication: Corpus-based Approaches to Language in the Digital World (pp. 192-219). Ljubljana: ZIFF.

Buzan, B., Waever, O., \& Wilde, de J. (1998). Security: A new framework for analysis. Boulder, Colorado: Lynne Rienner. 
van Dijk, T. A. (1991). Racism and the Press. London and New York: Routledge. van Dijk, T. A. (2001). Critical discourse analysis. In D. Schiffrin, D. Tannen \& H. E. Hamilton (Eds.), Handbook of discourse analysis, 349-371.

Erjavec, K., \& Kovačič, M. P. (2012). You Don’t Understand, this is a New War. Analysis of Hate Speech in News Websites' Comments. Mass Communication and Society, 15(6), 899-920.

European Council (2016). EU-Turkey Statement, 18 March 2016. Retrieved from https://www.consilium.europa.eu/en/press/press-releases/2016/03/18/ eu-turkey-statement/

Fairclough, N. (2001). Language and Power. London, New York: Longman.

Fišer, D., \& Beisswenger, M. (Eds.). (2017). Investigating Computer-Mediated Communication: Corpus-based Approaches to Language in the Digital World. Ljubljana: ZIFF.

Gorjanc, V., \& Fišer, D. (2018). Twitter in razmerja moči: diskurzna analiza kampanj ob referendumu za izenačitev zakonskih zvez v Sloveniji. Slavistična revija, 66(4), 473-495.

Gorjanc, V., \& Fišer, D. (2020). Twitter discourse on LGBTQ+ in Slovenia. In D. Fišer \& P. Smith (Eds.), The Dark Side of Digital Platforms: Linguistic Investigations of socially unacceptable online discourse practices (pp. 36-55). Ljubljana: ZIFF.

Huysmans, J. (2006). The politics of insecurity: Fear, migration and asylum in the EU. London: Routledge.

Innes, A. (2010). When the threatened become the threat: The construction of asylum seekers in British media narratives. International Relations, 4 , $456-477$.

Keren, G. (2011). On the definition and possible underpinnings of framing effects. Perspectives on framing, 3-33. New York: Taylor and Francis.

Kogovšek Šalamon, N. (2017). Mass Migration, Crimmigration and Defiance: The Case of Humanitarian Corridor. Southeastern Europe, 41(3), 251-275. Ladić, M., \& Vučko, K. (2016). Slovenia's response to increased arrivals of refugees: "We don't want them, but we also don't understand why they don't want to stay." In N. Kogovšek Šalamon \& V. Bajt (Eds.), Razor-wired: Reflections on migration movements through Slovenia in 2015 (pp. 7-10). Ljubljana, Slovenia: Peace Institute. 
Ljubešić, N., Fišer, D., \& Erjavec, T. (2019). The FRENK Datasets of Socially Unacceptable Discourse in Slovene and English. Retrieved from https:// arxiv.org/pdf/1906.02045.pdf

Merrill, S., \& Åkerlund, M. (2018). Standing Up for Sweden? The Racist Discourses, Architectures and Affordances of an Anti-Immigration Facebook Group. Journal of Computer-Mediated Communication 23(6), 332-353.

Sindoni, M. G. (2018). DIRECT HATE SPEECH VS. INDIRECT FEAR SPEECH: A multimodal critical discourse analysis of the Sun's editorial "1 in 5 Brit Muslims' sympathy for jihadis". Lingue e Linguaggi, 28, 267-292.

Slovenske novice (2015). VIDEO: Begunci zavračajo pomoč Rdečega križa? Retrieved from https://www.slovenskenovice.si/novice/svet/video-begunci-zavracajopomoc-rdecega-kriza

Vehovar, V., Povž, B., Fišer, D., Ljubešić, N., Šulc, A., \& Jontes, D. (2020). Družbeno nesprejemljivi diskurz na Facebookovih straneh novičarskih portalov. Teorija in praksa, 57(2), 622-645.

Vezovnik, A. (2017). Securitizing Migration in Slovenia: A Discourse Analysis of the Slovenian Refugee Situation. Journal of Immigrant and Refugee Studies, 16(1-2), 39-56.

Waldron, J. (2012). The Harm in Hate Speech. Cambridge: Harvard University Press.

Wodak, R., \& Boukala, S. (2015). European identities and the revival of nationalism in the European Union: A discourse historical approach. Journal of Language and Politics, 14(1), 87-109. 


\section{PERCEPCIJA GROŽNJE V PROTIMIGRANTSKEM GOVORU NA SPLETU: ŠTUDIJA PRIMERA}

Članek na osnovi kritične analize odzivov komentatorjev na medijske objave v času evropske migracijske krize opisuje percepcijo beguncev kot grožnje v slovenskem spletnem diskurzu. Raziskava izhaja iz stališča, da je dojemanje pojava migracij kot grožnje v središču družbeno nesprejemljivega diskurza, $\mathrm{v}$ katerem so begunci in migranti prikazani kot nezaželjen in potencialno nevaren element. V okviru celovitega projekta, ki je vključeval obravnavo javnih odzivov na medijsko poročanje o prihodu migrantov v Slovenijo, so bili za analizo izbrani komentarji, usmerjeni proti beguncem in migrantom. Relevantni komentarji so bili nato označeni z namenom opredelitve najpogostejših tematskih sklopov, vezanih na percepcijo grožnje. Besedilna analiza se osredotoča na opis glavnih kategorij domnevne grožnje ter na različne diskurzivne značilnosti in strategije, vsebovane v komentarjih. Čeprav obravnava pojava v večji meri temelji na kvalitativnem opisu, je $\mathrm{v}$ članku predstavljen tudi pregled pogostnosti in porazdelitve prepoznanih kategorij.

Ključne besede: korpusna analiza, kritična analiza diskurza, protimigrantski govor, sovražni govor, evropske migracije

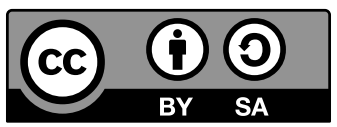

To delo je ponujeno pod licenco Creative Commons: Priznanje avtorstva-Deljenje pod enakimi pogoji 4.o Mednarodna. / This work is licensed under the Creative Commons Attribution-ShareAlike 4.0 International. 